\title{
Upper Stomach Disorder Detection System using Backpropagation Artificial Neural Network
}

\author{
Fitria Hidayanti, Hari Hadi Santoso, Handoko Endo Prasetyo \\ Engineering Physics Department, Universitas Nasional, Jakarta 12520 Indonesia \\ fitriahidayanti@gmail.com
}

\begin{abstract}
The study aims to make simple detection of upper stomach disorders of the iris image based on the chart to iridology, making an upper stomach disorder detection system using backpropagation artificial neural network method and determining the accuracy of the system. Backpropagation artificial neural networks is a type of neural network that trains the network to get a balance between the network's ability to recognize patterns used during training as well as networking capabilities to provide a correct response to similar input patterns but not identical with patterns during training. Iridology is the science of analyzing the subtle structures of the iris. This research was conducted from the shooting stage of the eye image using the camera, data obtained as 40 iris images. Detection of disorders using chart to iridology from the iris imagery data of 20 pairs of eyes consisting of left and right. This results of 10 pairs of eye image showed that upper stomach disorder and 10 pairs of eye image showed no upper stomach disorder.
\end{abstract}

Key words: Upper Stomach Disorder, Backpropagation Artificial Neural Network, Detection System, Iris Image, Iridology

\section{INTRODUCTION}

The development of health technology is growing from software-based health technology and hardware of equipment. Many applications use a smart base system based on expertise. It is revealed that many software technologies are used in diagnosing and detecting diseases. Some software uses its expert system in diagnosing and detecting. Some techniques are used in diagnosing such as a person's medical record technique which has become a database of disease detection. In addition, there is also a technique through iridology that gives results of medical analysis through the iris based on the chart to iridology. This technique is the easiest technique in diagnosing diseases because the iris itself for some researchers is referred to as the body. In his book, Jensen used his knowledge to diagnose a disease by iris [1].

In his research [2], Dewi et al. diagnose disease through the image processing and determine the illness through a neural network. The diseases that are observed are disorders of the stomach. Bansal et al. [3] detected a body disorder in iridology using simple image processing in his evidence. The result showed that iridology is an alternative technique that can be used by looking at the iris to find out the status of organs with a very effective introduction algorithm combined with iridology.

The detection technique using iridology [4] and assisted by simple image processing in the evidence is very interesting to be further researched. Therefore, this study will make the system of impaired detection of the body on the upper stomach with the method of backpropagation artificial neural network. The problems that can be diagnosed by iridology [5] are the body parts that are often affected by disorders, such as disorders of the liver [4] and pancreas organs [6, 7]. This makes the disorder easily detected in the iris of the human eye.

Iridology is a science that describes inflammation where the disease is shown from the eye. The iris section describes the body's structure where there is weakness, level of health, and 9 transitions that occur in one's body by way of life. More precisely, iridology is the science of analyzing the subtle structure of the iris of the eye colour [1].

The development of iridology [8] has been progressing very rapidly with the development of digital camera techniques that allow a perfect iris examination. Digital camera shooting can be enlarged with excellent image quality, allowing for more precise analysis and enabling standardization and the creation of more accurate and detailed topographical iris maps [9].

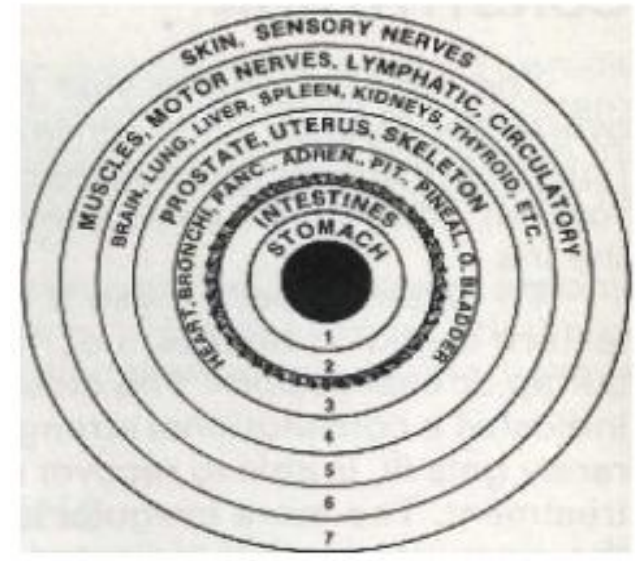

Figure 1: Topographic iris divided into 7 zones [1] 
To facilitate the global understanding of the iris is depicted topographically in 7 zones (Figure 1) topographic, namely (a) stomach, (b) bowel (small intestine and colon), (c) heart, throat, pancreas, adrenal glands, proliferation, pituitary and pineal, (d) prostate, uterine and skeletal bones, (e) brain, lungs, liver, spleen, kidney and thyroid gland, (f) muscle, motor nerve, lymph and circulatory, and $(\mathrm{g})$ sensory skin and nerves.

Topographical slices can not be representative to describe the role of iris right and left eye iris. Right-eye iris and left-eye iris have a role as information representative of the health condition of all our body organs. The organ of symmetry in the body is mapped in a chart to iridology as a pair of metric mirrors as well (Figure 2).

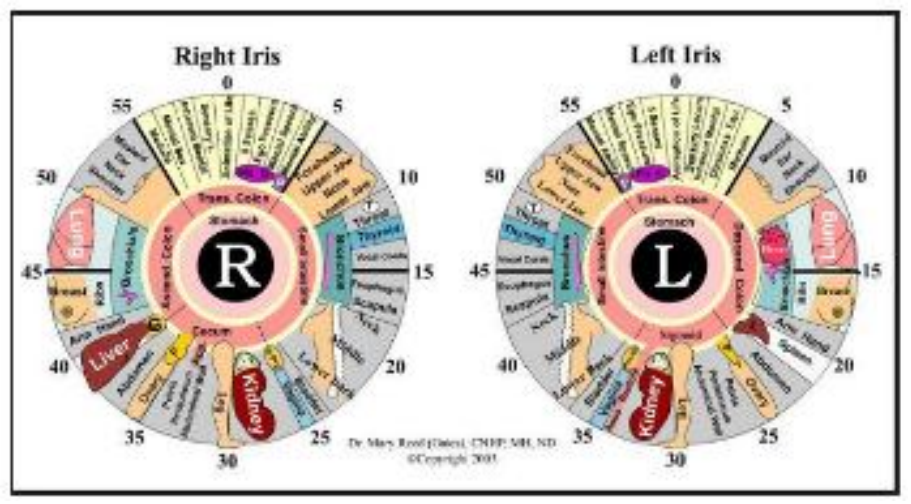

Figure 2: Chart to iridology [2]

\section{RESEARCH METHODS}

This research uses hardware such as (a) a Canon EOS 750D with EF telephoto Lens 55-250mm IS STM, (b) Laptop with 6 Gb of DDR3 RAM, (c) 13-watt lamps with illuminance 19.7 lux and software.

Matlab 2013A [10] is used for technical computing, integrating computing capabilities, visualizations and programming in a single environment. MATLAB provides an interactive system that uses an array or matrix concept as its standard variable elements without requiring the declaration of arrays as in other languages.

Computer Vision and Image Processing Tool (CVIPtool) [11] is a software for image processing. This software is used for image pre-processing before it proceeds by Matlab.

PhotoScape [2] software provides a handy tool in the image editing process. This software is used to cut the eye image into symmetrical so as to facilitate the image processing process.

\section{Data retrieval methods}

The data used in this research is primary [12-17]. Data was taken directly by photographing the right and left eye using the camera. Target this research to build the system of detection upper body disorders of the stomach from iris with backpropagation artificial neural network. The built-in system must have data to be processed and used on the system to detect whether or not a person has a body disorder on the upper part of the stomach.

The data used were the right and left eye image data taken using the camera. Several aspects should be considered in photographing eye image, including lighting and image capture position. When shooting, the distance of the camera lens with the object is $60 \mathrm{~cm}$ because the type of lens used is the lens for long-distance objects (telephoto lens EF-S55-250mm IS STM).

The colour of the photographed object is influential. If the colour is too dark, additional light should be used. This study used 13 watts lamps with illuminance 19.7 lux. Lighting placements are also very influential in the imagery obtained. The object used is an eye image, the eye can project the surrounding environment. Reflections from additional lighting or reflections from objects right in front of objects will have a great effect on the eye image. Therefore, the shooting is cultivated so that additional projections that can affect the imagery are reduced (Figure 3 ).

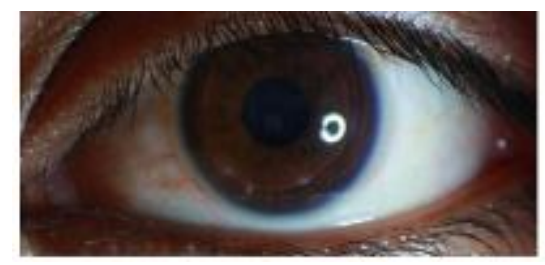

Figure 3: Left eye image of the shooting result

\section{Data processing methods}

The data obtained from the shooting results in the data retrieval process is as many as 20 pairs of eye images consisting of 20 right eyes and 20 left eyes. Imagery obtained from the shot must go through the pre-processing image-level before it is processed using the network terms of backpropagation.

\section{Stage of the pre-process}

Pre-process technique is an activity that consists of the process of cutting the image, image size change, image quality improvement, and image type change from RGB to grayscale (Figure 4).

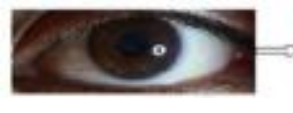

(a)

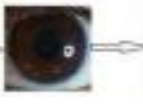

(b)

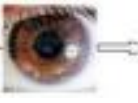

(c)

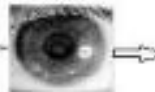

(d) (e)
Figure 4: Result stage of pre-processing (a) original image, (b) RGB image, (c) improved quality, (d) grayscale image, and (e) black and white image 


\section{Simple detection of upper stomach disorders using chart to iridology}

From simple detection using chart to iridology acquired 10 pairs of eye image detected, there is an upper stomach disorder.
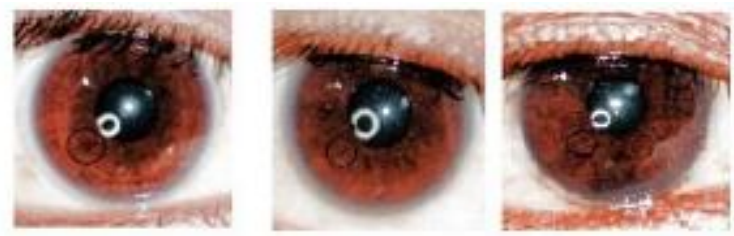

Figure 5: Iris image with a disorder based on chart to iridology

The black circle on the iris image is the position (Figure 5) of the wound in the iris, indicating that the image is the upper stomach disorder based on the chart to iridology.

\section{Training applications}

The application training (Figure 6) used in this study uses supervised learning training, by pairing the data (input with output target data) that is used to train the network until the desired weight is obtained. We must create the target data according to the existing inputs. The data used in this training program amounted to 20 iris image input data and 20 target data. The target is classified into 2 groups, namely the group with the upper stomach disorder and a group that has no upper stomach disorder. Each group is given a value of 1 and 0 .

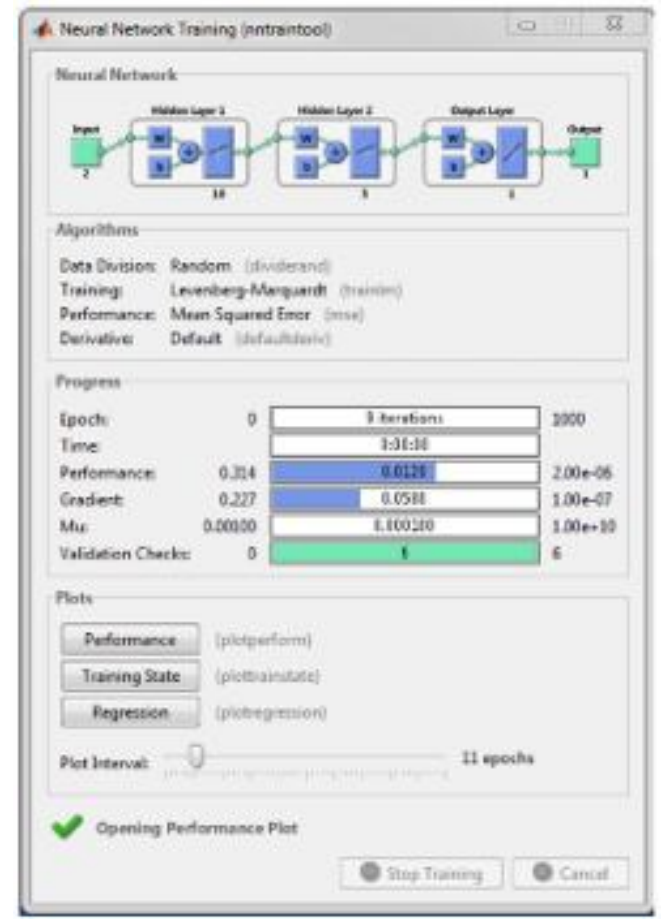

Figure 6: Training of backpropagation artificial neural network

The data pair serves as a "teacher" to train the network until the best form is obtained. "Teacher" will provide clear information about how the system should change itself to improve its work. At each training time, the input is given to the network. The network will modify the weights according to the errors.

The function uses network object data pool input and target data as training inputs and will produce the trained network objects, the final weight and information during training (epoch and performance functions) as output.

It was making apps smart by minimizing network performance by using Mean Square Error (MSE). This function will fetch the average squared error that occurs between the network output and the target. The basic principle of the backpropagation algorithm is to fix the network weight with the direction that makes the MSE performance function become a clone quickly. To accelerate the MSE's decline, there are 2 alternatives in the improvement, namely using heuristic techniques and numerical optimization techniques.

\section{RESULTS AND DISCUSSION}

\section{System testing of backpropagation artificial neural network}

The system testing of the backpropagation artificial neural network was conducted to determine the upper stomach disorder using an iris image using test data from 20 iris imagery. Results showed that 5 right eye image suffered upper stomach disorder, 5 right-eye images is not suffered the upper stomach disorder, 5 left eye image suffered upper stomach disorder and 5 left eye image is not suffered the upper stomach disorder. The process of testing a backpropagation artificial neural network has been made based on the training of iris imagery practice.

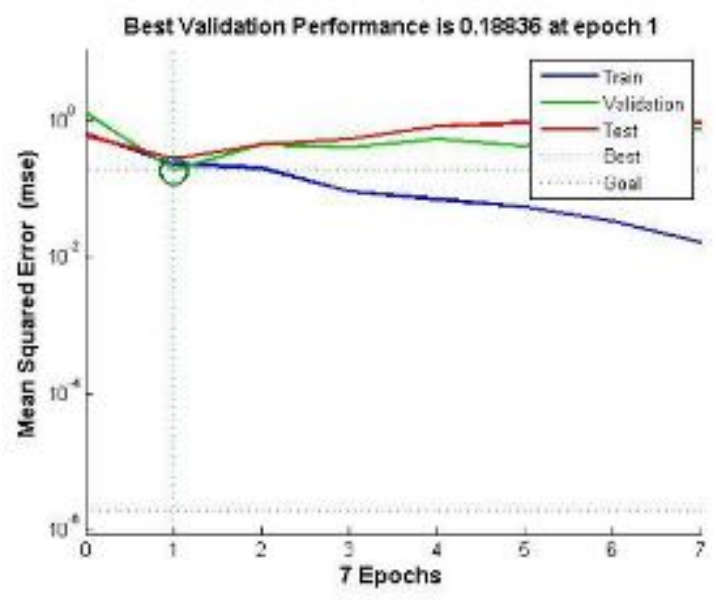

Figure 7: Performance of backpropagation artificial neural network

In Figure 7, the MSE value for the program only is 0.18836 on the first epoch. This signifies that the training program can work well. With the value of epoch only 7 , this can be stated that the training program goes well, because of the least epoch done, so that the training program can work well in recognizing its training pattern because the process of 
iteration goes well, stopping on the epoch to 7. Epoch is a presentation of a collection of vector training (input and/or target) to the network and calculation of new weights and biases.

The training vectors can be presented one by one or together in a single group or in other words, the epoch stated a loop of training that took place. In this study epoch which became the best performance is in the first epoch with its MSE value is 0.18836 where between the blue train line met with a green validation line, and the red test line meets the value shown on the chart of 0.18836 . This explains that the training occurred for 7 times the loop, where the train line, validation and test met at the value of 0.18836 in the first epoch, and next on each train line epoch, away from the test and validation lines. This happens because overfitting, i.e. data on the training set leads to a small value, and when new data is inserted into the network, its direction becomes large so that the training is away from the test line and the validation line.

(a)

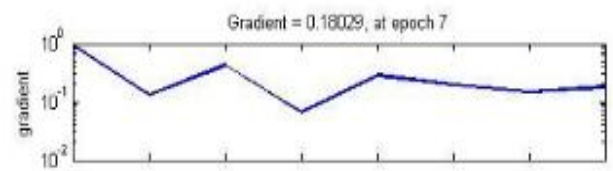

(b)
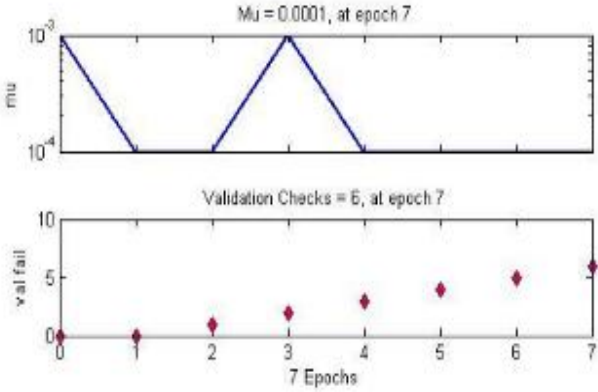

Figure 8: Training state of backpropagation artificial neural network, relationship the epoch with (a) gradient,

(b) $\mathrm{Mu}$, (c) validation file
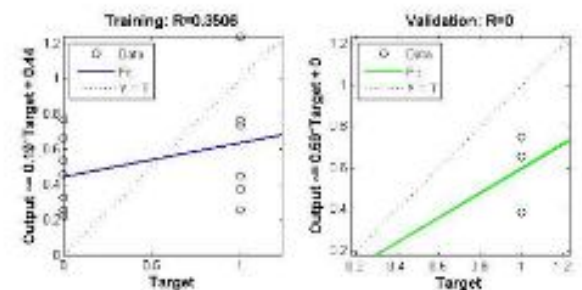

Tast: R-az816
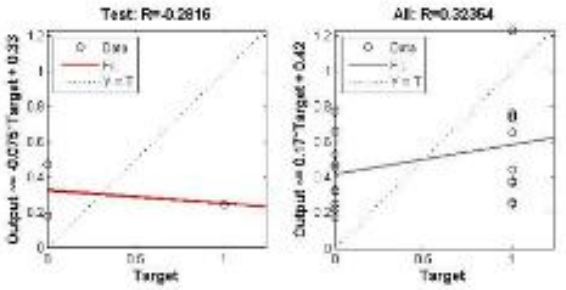

Figure 9: Regression of backpropagation artificial neural network
The gradient value (Figure 8) in this training process is 0.1029 , mu value of 0.0001 and validation check 6 on the 7 th epoch. This can indicate that the program can recognize the pattern well so that it has its validity value at 6 when the epoch expires to 7 .

Training program (Figure 9) approaching the introduction of iris imagery because on the first chart, the fit line was initially able to recognize the data but eventually moved away from the target because the input signal weight was lacking so that it moved away. The final value of the training was 0.32364 .

\section{Detection system testing of upper stomach disorders}

The upper stomach disorder detection system test was conducted against test data. The stage of the upper stomach disorder detection system is (a) open DiagnosaUAba. (b) select load image. The iris image you want to test in the "Test Data" folder, (c) after the iris image is selected, select Process to process the image in the black and white binary image, (d) the test result will be displayed under the Process button, and (e) click accuracy to see the accuracy value of the system.

Table 1: Image of Righ Eye 01-10

\begin{tabular}{|c|l|c|c|}
\hline No & Image name & Image type & Remarks \\
\hline 1 & right_eye_01.jpg & & $\begin{array}{c}\text { Upper } \\
\text { stomach } \\
\text { disorder }\end{array}$ \\
\hline 2 & right_eye_02.jpg & & $\begin{array}{c}\text { Upper } \\
\text { stomach } \\
\text { disorder }\end{array}$ \\
\hline 3 & right_eye_03.jpg & & $\begin{array}{c}\text { Upper } \\
\text { stomach } \\
\text { disorder }\end{array}$ \\
\hline 4 & right_eye_04.jpg & & $\begin{array}{c}\text { Upper } \\
\text { stomach } \\
\text { disorder }\end{array}$ \\
\hline 5 & right_eye_05.jpg & & $\begin{array}{c}\text { Upper } \\
\text { stomach } \\
\text { disorder }\end{array}$ \\
\hline 6 & right_eye_06.jpg & & $\begin{array}{c}\text { No Upper } \\
\text { stomach } \\
\text { disorder }\end{array}$ \\
\hline 7 & right_eye_07.jpg & & $\begin{array}{c}\text { No Upper } \\
\text { stomach } \\
\text { disorder }\end{array}$ \\
\hline 8 & right_eye_08.jpg & & $\begin{array}{c}\text { Upper } \\
\text { stomach } \\
\text { disorder }\end{array}$ \\
\hline 9 & right_eye_09.jpg & & $\begin{array}{c}\text { Upper } \\
\text { stomach } \\
\text { disorder }\end{array}$ \\
\hline 10 & right_eye_10.jpg & & $\begin{array}{c}\text { No Upper } \\
\text { stomach } \\
\text { disorder }\end{array}$ \\
\hline & & & \\
\hline
\end{tabular}


Fitria Hidayanti et al., International Journal of Emerging Trends in Engineering Research, 8(8), August 2020, 4426 - 4432

Table 3: Image of Left Eye 01-10

Table 2: Image of Right Eye 11-20

\begin{tabular}{|c|l|c|c|}
\hline No & Image name & Image type & Remarks \\
\hline 11 & right_eye_11.jpg & & $\begin{array}{c}\text { No Upper } \\
\text { stomach } \\
\text { disorder }\end{array}$ \\
\hline 12 & right_eye_12.jpg & $\begin{array}{c}\text { No Upper } \\
\text { stomach } \\
\text { disorder }\end{array}$ \\
\hline 13 & right_eye_13.jpg & & $\begin{array}{c}\text { No Upper } \\
\text { stomach } \\
\text { disorder }\end{array}$ \\
\hline 14 & right_eye_14.jpg & & $\begin{array}{c}\text { No Upper } \\
\text { stomach } \\
\text { disorder }\end{array}$ \\
\hline 15 & right_eye_15.jpg & & $\begin{array}{c}\text { Upper } \\
\text { stomach } \\
\text { disorder }\end{array}$ \\
\hline 16 & right_eye_16.jpg & & $\begin{array}{c}\text { No Upper } \\
\text { stomach } \\
\text { disorder }\end{array}$ \\
\hline 17 & right_eye_17.jpg & & $\begin{array}{c}\text { Upper } \\
\text { stomach } \\
\text { disorder }\end{array}$ \\
\hline 18 & right_eye_18.jpg & & $\begin{array}{c}\text { No Upper } \\
\text { stomach } \\
\text { disorder }\end{array}$ \\
\hline & right_eye_19.jpg & & $\begin{array}{c}\text { No Upper } \\
\text { stomach } \\
\text { disorder }\end{array}$ \\
\hline & & & $\begin{array}{c}\text { Upper } \\
\text { stomach } \\
\text { disorder }\end{array}$ \\
\hline & & & \\
\hline
\end{tabular}

Results of 20 iris images detected, as many as 11 iris images were detected according to simple detection using a chart to iridology, while the 9 eyes image was not suitable with simple detection using the chart to iridology. This corresponds to the value of accuracy obtained from the backpropagation artificial neural network system obtained that is $55 \%$.

Detection based on chart to iridology was done against 40 iris imagery (Table 1 - Table 4). Results showed that 10 pairs of iris imagery (10 Right iris imagery and 10 left iris imagery) experienced upper stomach disorders and 10 pairs of iris imagery (10 right iris imagery and 10 left iris imagery) did not suffer from the upper stomach disorder. The cuts on the iris image are based on the chart to iridology indicating that the upper stomach disorder.

Pre-processing of imagery is done using PhotoScape software to crop an image of the same size and resize the image to $240 \times 240$ pixels. CVIPtools Software is used to enhance the image quality and convert the RGB image into a grayscale image.

\begin{tabular}{|c|c|c|c|}
\hline No & Image name & Image type & Remarks \\
\hline 1 & left_eye_01.jpg & & $\begin{array}{l}\text { Upper } \\
\text { stomach } \\
\text { disorder }\end{array}$ \\
\hline 2 & left_eye_02.jpg & & $\begin{array}{l}\text { Upper } \\
\text { stomach } \\
\text { disorder }\end{array}$ \\
\hline 3 & left_eye_03.jpg & & $\begin{array}{l}\text { Upper } \\
\text { stomach } \\
\text { disorder }\end{array}$ \\
\hline 4 & left_eye_04.jpg & & $\begin{array}{l}\text { Upper } \\
\text { stomach } \\
\text { disorder }\end{array}$ \\
\hline 5 & left_eye_05.jpg & & $\begin{array}{c}\text { Upper } \\
\text { stomach } \\
\text { disorder }\end{array}$ \\
\hline 6 & left_eye_06.jpg & & $\begin{array}{c}\text { No Upper } \\
\text { stomach } \\
\text { disorder }\end{array}$ \\
\hline 7 & left_eye_07.jpg & & $\begin{array}{l}\text { No Upper } \\
\text { stomach } \\
\text { disorder }\end{array}$ \\
\hline 8 & left_eye_08.jpg & & $\begin{array}{c}\text { Upper } \\
\text { stomach } \\
\text { disorder }\end{array}$ \\
\hline 9 & left_eye_09.jpg & & $\begin{array}{c}\text { Upper } \\
\text { stomach } \\
\text { disorder }\end{array}$ \\
\hline 10 & left_eye_10.jpg & & $\begin{array}{l}\text { No Upper } \\
\text { stomach } \\
\text { disorder }\end{array}$ \\
\hline
\end{tabular}

Training of backpropagation artificial neural network using target data 1 and 0 with 1 for the eye image of the upper stomach disorder and 0 for the eye image that there is no upper stomach disorder. These two targets correspond to the desired output so that the backpropagation artificial neural network training system can recognize the data entered in accordance with the target. The data used for training is 20 iris image consisting of 5 right-eye images with an upper stomach disorder, 5 right eye image that there is no upper stomach disorder, 5 left-eye images with the upper stomach disorder and 5 left-eye images that there is no upper stomach disorder. 
Fitria Hidayanti et al., International Journal of Emerging Trends in Engineering Research, 8(8), August 2020,4426 - 4432

Table 4: Image of Left Eye 11-20

\begin{tabular}{|c|c|c|c|}
\hline No & Image name & Image type & Remarks \\
\hline 11 & left_eye_11.jpg & & $\begin{array}{l}\text { No Upper } \\
\text { stomach } \\
\text { disorder }\end{array}$ \\
\hline 12 & left_eye_12.jpg & & $\begin{array}{l}\text { No Upper } \\
\text { stomach } \\
\text { disorder }\end{array}$ \\
\hline 13 & left_eye_13.jpg & & $\begin{array}{l}\text { No Upper } \\
\text { stomach } \\
\text { disorder }\end{array}$ \\
\hline 14 & left_eye_14.jpg & & $\begin{array}{l}\text { No Upper } \\
\text { stomach } \\
\text { disorder }\end{array}$ \\
\hline 15 & left_eye_15.jpg & & $\begin{array}{c}\text { Upper } \\
\text { stomach } \\
\text { disorder }\end{array}$ \\
\hline 16 & left_eye_16.jpg & & $\begin{array}{l}\text { No Upper } \\
\text { stomach } \\
\text { disorder }\end{array}$ \\
\hline 17 & left_eye_17.jpg & & $\begin{array}{c}\text { Upper } \\
\text { stomach } \\
\text { disorder }\end{array}$ \\
\hline 18 & left_eye_18.jpg & & $\begin{array}{l}\text { No Upper } \\
\text { stomach } \\
\text { disorder }\end{array}$ \\
\hline 19 & left_eye_19.jpg & & $\begin{array}{c}\text { No Upper } \\
\text { stomach } \\
\text { disorder }\end{array}$ \\
\hline 20 & left_eye_20.jpg & & $\begin{array}{c}\text { Upper } \\
\text { stomach } \\
\text { disorder }\end{array}$ \\
\hline
\end{tabular}

\section{CONCLUSION}

Detection of body disorders using the chart to iridology of the 20 pairs of iris-image data consisting of left and right is detected as much as 10 pairs of eye image suffered by upper stomach disorder and 10 pairs of eye image did not suffer upper stomach disorder. The upper stomach disorder detection system is made using the backpropagation artificial neural networks method. In 20 eye data tested were obtained 11 iris imagery that corresponds to the detection using chart to iridology and 9 inappropriate iris imagery.

\section{ACKNOWLEDGEMENT}

Thank you for Lembaga Penelitian dan Pengabdian kepada Masyarakat (LPPM) Universitas Nasioal and my colleagues at Faculty of Engineering and Science, Universitas Nasional, Jakarta, Indonesia.

\section{REFERENCES}

1. Jensen, B., Iridology simplified. Book Publishing Company. 2012.

2. Dewi, A.K., A. Novianty, and T.W. Purboyo. Stomach disorder detection through the iris image using backpropagation neural network. in 2016 International Conference on Informatics and Computing (ICIC). IEEE. 2016.

3. Bansal, A., R. Agarwal, and R. Sharma, Determining diabetes using iris recognition system. International journal of diabetes in developing countries, 2015. 35(4): p. 432-438. 2015.

https://doi.org/10.1007/s13410-015-0296-1

4. Lestari, R.F., H.A. Nugroho, and I. Ardiyanto. Liver Detection Based on Iridology using Local Binary Pattern Extraction. in 2019 2nd International Conference on Bioinformatics, Biotechnology and Biomedical Engineering (BioMIC)-Bioinformatics and Biomedical Engineering. IEEE. 2019.

5. Pau, G., The Foundations of Iridology: The Eyes as the Key to Your Genetic Health Profile. Simon and Schuster. 2019.

6. Putri, R. and A.H. Saputro. Implementation of Neural Network Classification for Diabetes Mellitus Prediction System through Iridology Image. in 2019 6th International Conference on Information Technology, Computer and Electrical Engineering (ICITACEE). IEEE. 2019.

7. Asuntha, A., Siddartha, M., Udhaykumar, K., and Srinivasan, A. Identification of Diabetics Mellitus using Iridology. International Journal of Research in Pharmaceutical Sciences, 10(3), 1821-1823. 2019.

8. Miranda, J.D. and S.A. Salinas. Computational Measuring Approach for the Identification of Probable Intestinal System Pathologies through the Human Iris Parameters. in 2019 XXII Symposium on Image, Signal Processing and Artificial Vision (STSIVA). IEEE. 2019.

9. Battello, C., Iridology-Advances: A New triad. DIGITALIZA. 2016.

10. Dimililer, K., Y.K. Ever, and H. Ratemi, Intelligent eye tumour detection system. Procedia Computer Science, 102: p. 325-332. 2016. https://doi.org/10.1016/j.procs.2016.09.408

11. Othman, Z., Ahmad, A., Kasmin, F., Ahmad, S. S. S., Sari, M. Y. A., and Mustapha, M. A. Comparison between edge detection methods on UTeM unmanned arial vehicles images. In MATEC Web of Conferences (Vol. 150, p. 06029). EDP Sciences. 2018

12. Hidayanti F., Wati E.K., and Akbar H. Energy Harvesting System Design for Converting Noise into Electrical Energy. International Journal of Advanced Science and Technology. 29(03), 4791 - 4802. 2020.

13. Hidayanti F., Lestari K.R., and Anwar R. Arduino Based Conductive Silver Lamination 
Fitria Hidayanti et al., International Journal of Emerging Trends in Engineering Research, 8(8), August 2020, 4426 - 4432

Device. International Journal of Emerging Trends in Engineering Research. 8(2), 265 - 270. 2020. https://doi.org/10.30534/ijeter/2020/04822020

14. Hidayanti F., Santoso H. H., and Amalia D. Induction Measurement of Extra High Voltage Air Duct. International Journal of Emerging Trends in Engineering Research. 8(4), 1424 - 1427. 2020. https://doi.org/10.30534/ijeter/2020/78842020

15. Hidayanti F., Rahmah F., and Wiryawan A. Design of Motorcycle Security System with Fingerprint Sensor using Arduino Uno Microcontroller. International Journal of Advanced Science and Technology. 29(05), 4374 - 4391. 2020.

16. Hidayanti F., Rahmah F., and Sahro A. Mockup as Internet of Things Application for Hydroponics Plant Monitoring System. International Journal of Advanced Science and Technology. 29(05), 5157 - 5164. 2020.

17. Hidayanti F., Wati E.K., and Miftahudin M. F. Design of Energy Harvesters on Motorcycle Exhaust using Thermoelectric Generator for Power Supply Electronic Device. International Journal of Renewable Energy Research. 10(1), 251 - 259. 2020. 